\title{
OUTRAS HISTÓRIAS \\ A VÊNUS, O OLHO E A MULATA EM DESMONTE ONTOLÓGICO
}

Renata Carmo Alves é doutoranda do Programa de Pós-Graduação em Literatura, Cultura e Contemporaneidade da PUC-Rio.

\section{Resumo}

Este ensaio procura refletir sobre a construção de uma esteriotipização do corpo feminino negro a partir, principalmente, da personagem Saartje Baartman, a Vênus Hotentote. A questão contemporânea passa pela diversidade, pela junção daquilo que é universal com a diferença. A diferença é complementar. No cerne de uma reflexão ética o lugar de complemento se dá no entre, não mais na configuração do contexto de Saartje, mas sim em um novo lugar de escuta e de fala, um diálogo que se estabelece através das diferenças.

\section{Palavras-chave}

Saartje Baartman. Diferença. Necropolítica. Esteriotipização. Diáspora.

Escrever é uma maneira de sangrar

(EVARISTO, 2016:109).

Sob o lodo há mais gente que suspira...

(ALIGHIERI, 2003:645).

Saartje Baartman. Deram-lhe um nome. Deram-lhe outro nome: Sarah. Deramlhe ainda outro nome: Vênus Hotentote ${ }^{1}$. Deram-lhe um corpo. Saartje foi levada da África para a Inglaterra em 1810 por um agricultor bôer da região do Cabo (África do Sul), e por um médico. Saartje não era uma mulher, e era uma mulher. Era uma africana, isso que chamam de negra. Parecia uma mulher, mas não era uma mulher. Ela foi exibida como um animal selvagem por cerca de cinco anos em Londres e em Paris. A senhora Saartje era a personificação do outro, outro corpo, um outro outro. Saartje: a mulher-macaco; a mulher-orangotango; a mulher-nádegas; a mulher-coisa; a mulherobjeto; a objeto-coisa; a macaco-nádegas; a coisa-mulher; a orangotango-coisa.

A senhora Saartje Baartman era exposta no palco e precisava caminhar em sua jaula de objeto-coisa acorrentada pelos pés quando era ordenada. Exibida como um espetáculo popular, a mulher-orangotango era um absoluto sucesso junto ao público

\footnotetext{
${ }^{1}$ Todas as palavras que estiverem em itálico neste ensaio correspondem a termos, ideias ou conceitos forjados dentro do regime colonial epistêmico. Tendo em vista o exercício de desconstrução ontológica proposta no ensaio, considero a adoção deste gesto um passo importante para nossa reflexão.
} 
geral - embora fosse absolutamente abusada. Sendo a representação do primitivo servia aos interesses ávidos de naturalistas e etnólogos. Foi medida, desenhada, vasculhada, observada, descrita e escrita. Saartje Baartman foi escrita. Para Saartje, a partir de Saartje, através de Saartje, fizeram moldes de cera e gesso, modelos, analisaram cada detalhe de sua anatomia, morta e viva. Saartje, a mulher-anomalia. Em nome da Ciência, a pesquisa. Uma ferramenta, um mecanismo para a construção de algo que Michel Foucault (2003), em suas considerações sobre as relações de poder estabelecidas socialmente, iria chamar no futuro de "regime de verdade" (FOUCAULT, 2003:10) - a criação através do poder e do conhecimento. O poder organiza uma anatomia-política do ser humano, desta forma os regimes de verdade são produtos de uma tecnologia do poder que, assim como a disciplinarização dos corpos, articulam uma intenção de verdade e ordenam o discurso de inserção no mundo a partir do corpo. Ademais, Saartje não era uma mulher. Não era senhora. Era uma coisa. Besta-coisa.

A Vênus Hotentote foi constituída como discurso. Era a personificação da diferença, era a representação da alteridade que nela estava patologizada. A Vênus tinha 1,37 metro de altura, mas ninguém pode dizer que foi este o aspecto que mais "interessou" aos senhores da razão, e sim sua esteatopigia: as nádegas protuberantes características da anatomia hotentote e o que chamaram de "avental hotentote". Tratavase de um alongamento dos lábios vaginais causado pela manipulação da genitália, aspecto considerado bonito por hotentotes e bosquímanos. Ela estava fora das codificações etnocêntricas, foi construída socialmente como o outro. Mais do que isso: ela validava a fantasia-obsessão da instituição desse outro pela marcação da diferença. Estereotipagem, fantasia e fetiche em nome da ciência, encarnados em Saartje Baartman, a Vênus Hotentote.

A Vênus Negra foi observada por meio de oposições binárias, tendo o corpo como significante primordial. Ele era a prova da Verdade, de sua existência primitiva, não civilizada, não igual - habitante de uma zona de vizinhança animal-homem, certamente mais animal que homem. Para a Ciência ela poderia ser, inclusive, o "entre": o estágio de evolução perdido entre o macaco e o homem. A genitália primitiva de Saartje era também o apetite sexual primitivo de Saartje. Embora não fosse dela o apetite que a encapsulava num lugar de exploração. Inserida no contexto da natureza, encerrada em sua suposta biologia, aprisionada no signo, a africana era a evidência da diferença irremediável entre as raças. Raças construídas socialmente de forma a serem 
regimentadas como distintas biologicamente. Para Saartje a biologia determinava o seu lugar e seu papel na história, justificando-se contra ela todo tipo de sadismo.

Na Europa do século XIX, a mulher Saartje, narrada como africana, era exibida como uma curiosidade de feira. Engana-se quem acredita que a história da Vênus Negra se trate exclusivamente de uma narrativa ficcional, a exemplo da película do francotunisiano Abdellatif Kechiche. Saartje é real, sua experiência pode nos ajudar a compreender como os regimes de representação e visibilidade, desde suas origens como estratagemas de poder e dominação, ainda orientam a leitura do que se entende por outro. A sociedade lê e formula tudo aquilo que não identifica como similar como sendo o outro: um não igual, minoritário, desimportante, um exótico. Nas decodificações sobre a alteridade, nas formulações sobre a diferença, nas percepções elaboradas a partir das reivindicações identitárias, se dá um jogo constituído numa relação olhar-mente. Ele ganha músculos na dinâmica das operações simbólicas em seus estágios de inserção e coerção, de manipulação e opressão, de estratégia e violência. De tempos em tempos, e sempre, o manejo da exclusão se reconfigura.

A Vênus Hotentote era uma mulher-gorila: uma fera em forma feminina, usada para ganhos monetários. Ela, a mulher "entre", a mulher "coisa", uma "coisa nenhuma". Sarah, nome pelo qual também ficou conhecida, deu lucro a seu "empresário" não apenas como mulher-objeto/abjeto nas feiras europeias de fenômenos bizarros ou nos zoos humanos, mas também no acordo realizado com o Museé de L'Homme, em Paris, para que realizassem exames físicos. O mesmo museu que viria a ser a morada póstuma de Sarah, um corpo vilipendiado, devastado pela exploração e pelo racismo colonial mesmo depois de morto. Um corpo - ou pedaços de um corpo - lido como objeto passível de ser ridicularizado diante de um outrem, autorizado a ser usado, manipulado, olhado, pulverizado. Tocado, aviltado, mutilado, punido, exterminado. Um corpo a ser consumido. Parece familiar?

A senhora Saartje Baartman foi reduzida a seu corpo e a seus órgãos sexuais, que se tornaram os significantes de seu lugar na ordem "natural" das coisas, e seu lugar de coisa nenhuma. A natureza estava para a Vênus assim como Saartje Baartman estava para a jaula e o laboratório. Por isso Stuart Hall irá recuperar o livro "Diferença e patologia" (1985), no trecho "Estrutura profunda dos estereótipos", do historiador Sander Gilman, para refletir sobre a "forma extrema de reducionismo": "as partes dela que foram preservadas funcionavam, de forma essencializadora e reducionista, como 
'um resumo patológico do indivíduo inteiro"”(HALL, 2016:205). Ela sofre um desmonte final quando suas partes, assim como modelos, moldes, preservados no Museé de L'Homme, a tornaram um completo não-ser, uma coleção de pedaços exibidos em potes. O cérebro, o esqueleto e as partes sexuais da Vênus Hotentote continuaram sendo exibidos no museu até 1974. Apenas em 2002, o governo da África do Sul, através de Nelson Mandela, consegue recuperar os restos mortais da mulher. Ele lhe oferece um enterro com direito a discurso sobre a herança e a identidade africana além de honras de chefe de Estado: para ela, e para os outros, "iguais" a ela, que entendiam a necessidade de um cérebro e de órgãos genitais, conservados em dois potes de vidro no formol, serem enterrados na terra natal, em Hankey, 192 anos depois de Saartje Baartman ter sido levada para a Europa. Nos termos do fetichismo, a Vênus Negra foi fragmentada, as partes substituíram o todo, o objeto substituiu o sujeito. Saartje Baartman sequer existia como pessoa. Ela foi desintegrada pelo olhar. O olhar de um outro que a via, mas não via. Um olho que a reduzia e a limitava. Saartje Baartman é um caso abissal de total invisibilidade na superexposição - um corpo negro mirado, exposto, superexposto e nunca visto. Parece familiar?

Acredita-se que Saartje Baartman tenha nascido na Província Oriental do Cabo da África em 1789, sendo pertencente ao povo Khoisan, a mais antiga etnia humana da parte meridional da África, que os invasores europeus chamaram de hotentotes e bosquímanos. Ela teria perdido a mãe aos dois anos e o pai teria morrido quando era bastante jovem. A mulher teria tido um companheiro, assassinado por um colono holandês; com seu companheiro parece ter tido um bebê, também morto. Saartje, ainda bastante jovem, foi assumida como serva pela família Baartman - agricultores holandeses que moravam nas proximidades da Cidade do Cabo. Eles a deram o nome de Saartje (pequena Sarah). Em outubro de 1810 ela teria assinado um contrato com o cirurgião inglês William Dunlop e o empresário Hendrik Cesars, dono da casa onde trabalhava, que teriam dito que ela viajaria para a Inglaterra para fazer espetáculos. Saartje Baartman era analfabeta, entretanto assinara um contrato. Nos tais "espetáculos" a mulher fumava cachimbo, usava uma roupa justa da cor de sua pele, dançava, tocava instrumentos, usava plumas e contas, correntes nos pés, rastejava, andava nua e de quatro (somente com a vagina coberta) de forma a ressaltar sua "natureza animalesca" e, nos casos dos clientes mais abastados, estes tinham direito a demonstrações privadas em 
suas casas, nas quais era permitido que os convidados tocassem nela. ${ }^{2}$

A Vênus excursionou pela Grã-Bretanha, pela Irlanda e pela França, e quando Cesars retornou à África do Sul, ela foi parar nas mãos de um "amestrador de animais", cujo nome era Reaux. O homem a exibiu por cerca de 15 meses fazendo propagandas públicas de suas nádegas e de seu órgão sexual. Ela chegou a posar nua para retratos científicos no Jardin Du Roi, em Paris; foi examinada pelos cientistas mais importantes da época, entre os quais o celebrado médico naturalista Georges Cuvier, responsável pela dissecação do corpo da mulher, removendo toda a sua genitália, o cérebro e o esqueleto. Sarah morreu aos 26 anos de idade por conta de uma doença descrita como inflamatória e eruptiva. $\mathrm{O}$ domador de animais vendeu seu corpo para anatomistas para que não tivesse de arcar nem mesmo com as despesas do enterro. $\mathrm{O}$ esgotamento total deste corpo talvez possa nos conduzir a uma reflexão sobre o que de fato é abjeto: os arquétipos sociais nos quais encerramos indivíduos distintos e as naturalizações diárias do racismo.

Na performatividade dos discursos há deslocamentos através da reiteração, há um exercício semiótico que tanto mobiliza o tempo histórico quanto é permeado por ele. Os restos mortais de Sarah, repatriados, enterrados por Mandela em Hankey, falam sobre ela, mas falam também a respeito dos africanos e diaspóricos espalhados pela Terra. Para determinadas mensagens que modulam a compreensão e normatizam o pensamento social, haverá uma demanda contínua por reparação. Haverá reivindicações identitárias e disputas de narrativas no campo estético e no pragmático. A questão do contemporâneo é primeiro uma questão narrativa, um terreno de disputa simbólica que orienta e (re)organiza a vida, (re)inventa o cotidiano, (re)direciona a política, estressando os regimes de verdade impostos. O cotidiano é, portanto, político. Era quando enxertaram Saartje na Europa como Vênus, e é hoje, em meio às atrocidades contemporâneas e disputas de povos diaspóricos por reparação e direito às cidades e ao mundo - este que, ao mesmo tempo, lhe foi imposto e lhe foi impedido. As criaturas do zoo humano global não optaram por serem cosmopolitas, elas são. (APPIAH, 1998) Em suas constituições cidadãs, no interior de suas casas, em suas comunidades, em seus bairros de subúrbio (que bem lembram cidadelas romanas), em seus trânsitos

\footnotetext{
${ }^{2}$ Informações retiradas dos textos "Sarah Baartman: a chocante história da africana que virou atração de circo", escrito por Justin Parkinson, da BBC, e "As Vênus Negras", escrito por Ana Ferraz, da Carta Capital; ambos publicados no portal Geledés - Instituto da Mulher Negra. Disponível em: https://www.geledes.org.br/sarah-baartman-a-chocante-historia-da-africana-que-virou-atracao-de-circo/ e https://www.geledes.org.br/as-venus-negras/
} 
subalternos pelo globo.

O que é ser negro? Este ser inventado, de etnicidade fictícia, desterritorializado, pilhado, que ora é outro, ora é o mesmo - um duplo de historicidade fabular. Uma (re)invenção, que num momento é o novo, em outro se encontra aprisionado em um estereótipo talhado no tempo. Que ora é "apenas humano", ora é encerrado em sua negritude histórica - a depender dos interesses em jogo. O que é o negro, afinal? Achille Mbembe (2014) vai dizer que o negro e o branco representam duas figuras gêmeas do delírio que a modernidade produziu:

Ao reduzir o corpo e o ser vivo a uma questão de aparência, de pele, de cor, outorgando à pele e à cor o estatuto de uma ficção de cariz biológico (...) fizeram do Negro e da raça duas versões de uma única e mesma figura, a da loucura codificada (MBEMBE, 2014:11).

Como consequência da lógica de autoficção, o negro e a raça têm constantemente significado a mesma coisa. Esse ser fabular que precisa (re)fabular, desafiar a memória coletiva, transmutá-la inúmeras vezes, estressá-la a partir do cerne das significações às quais ela está submetida.

Quando o colonizador se coloca como a História e conta o outro como etnografia, a árvore da vida é cortada para ser introduzida num outro espaço-tempo nas Américas, na Europa e em todo lugar. A cultura e as especificidades de cada povo foram sufocadas pela violência tanto da colonização quanto da modernidade global. É a partir do deslocamento que as identidades diaspóricas irão se constituir, nas duplas, ou triplas, inscrições no mundo que vão se formuladas. É, portanto, a partir destas identidades constituídas no deslocamento, espoliadas, configuradas a partir de processos de clivagem social que formas de existir no mundo vão se definir, que maneiras de lutar por pertencimento no mundo vão se configurar como possibilidade de vida. É a partir das relações que o Ocidente estabeleceu com o que nomeou como o outro que se dá no tempo presente a leitura de mundo como o conhecemos. Será com ela que vamos nos relacionar, mesmo quando para negá-la, transpô-la, rejeitá-la, reinventá-la ou ultrapassála. Dentro dos regimes de representação, este outro, ainda que se queira igual, precisa encarnar a diferença - ela é uma marca. ${ }^{3}$ O corpo do outro é discurso. Este é sempre contado a partir da marcação da diferença que lhe foi imposta, dentro do processo de

\footnotetext{
${ }^{3}$ (APPIAH, 1998:41, grifo meu). "Nós não temos de tratar decentemente pessoas de outras culturas e tradições apesar de nossas diferenças; podemos tratar os outros decentemente, humanamente, através de nossas diferenças".
} 
polarização. Ainda que para fins de "igualdade", para torcer o significado, a mesma diferença é convocada. É um paradoxo.

O que é ser Saartje Baartman, afinal? O que é ser uma mulher negra? O que é ser uma mulher negra marcada pelo deslocamento? O que é ser uma mulher negra no Brasil? O que é não ser? Ser Saartje Baartman e não ser Saartje Baartman é ser fora de si mesma? É ser a partir do outro, a partir de um olhar determinante do outro? É ter a fragilidade impedida e o espírito continuamente saqueado? É ter a subjetividade (des)construída fora do próprio corpo? É desmaterializar-se, fragmentar-se, desconstituir-se e reconstituir-se? É estar no paradoxo e ser paradoxal? É existir SarahBaartman? É existir (como) Sarah-Baartman?

Se a pequena Sarah tinha se tornado um objeto de uso, objeto de exploração, há nesta dinâmica estabelecida, nesta relação que se dá entre o observador e o que é observado (esse outro), uma distância. Uma dupla distância. E não será a partir desta dupla distância regimentada que também se constituirá “o outro do outro" (RIBEIRO, 2017:44)? Com que olhos de Vênus olhava Sarah para aqueles que a objetificavam? Com que olhos devia olhar a criatura? Provavelmente com um olhar negro esbugalhado como aqueles que vemos codificados em filmes que tivemos a oportunidade de assistir, aprisionados em "tipos" estáticos aos quais fomos apresentados ao longo da história do cinema ou mesmo em programas de televisão. (ARAÚJO, 2000) Personagens que encerraram, talvez, a natureza de um "tipo" de olhar, possivelmente cheio de horror e de espanto, e que potencialmente confere a ele uma forma de ridículo, um arcabouço de risível. E com que olhos afinal olhava a Ciência para as partes mutiladas do corpo de Saartje?

\section{A dupla distância}

A estereotipagem é um manejo do poder que opera simbolicamente no mundo através da linguagem, encontrando suas formas de dizer através da cultura, da literatura, da produção de conhecimento, dos sentidos, das imagens de um determinado regime visual, implicando na própria vida. Os estereótipos evocados hoje, como manipulação do imaginário, como forma de ainda mostrar domínio sobre a imagem do indivíduo negro e assim defini-lo, são ecos desse passado constante, que chocam por sua insistência débil. Eles revelam uma face maniqueísta, onde a 
operação simbólica é também opressão simbólica. Eles demarcam um lugar, definem as margens sociais como estáticas - e operar esse campo é intervir no espaço-tempo, inventar, reordenar a práxis. O campo simbólico requer escolha (por produção de sentido), e que não existe fora da vontade do operador. Nisto não há inocência. $O$ imaginário está constantemente em disputa. Uma disputa que se dá nele e a partir dele: transborda para a "realidade" onde se estabelece um jogo perigoso de extermínio tanto físico quanto simbólico. Foi esse mesmo campo que gestou Sarah. Foi nele que Sarah nasceu. Ele a pariu. Ela: uma mulher-objeto; a mulher-abjeto; a menor destas criaturas; a que menos importa na escala social. Aliás, a propósito da Vênus, a anotação de Gilman, ainda em Stuart Hall (2016), aponta que "diziam” dela que muito provavelmente a Europa nunca mais veria uma pagã com uma bunda tão pesada. (HALL, 2016:205)

O etnólogo Maurice Leenhardt ${ }^{4}$, em uma determinada relação com um outro outro (que não é um outro negro, mas um outro-canaque), pergunta a um dos seus informantes a respeito de seu período de contato com os primitivos Kanak:

"No fim de contas, nós vos trouxemos o espírito, não foi?". Ao que o canaque respondeu: "O espírito? Não, não, o espírito já nós o tínhamos; o que vocês nos trouxeram foi o corpo" (GIL, 2002).

Conforme José Gil afirma a partir deste trecho, "a consciência do corpo tira então a sua potência de ser imanente ao mundo, de poder devir" (GIL, 2002). Quanto ao corpo, na consciência de um estatuto, em sua codificação, na coisificação de um corpo descolado de si mesmo, ele está encerrado em uma não-poiéses. Saartje Baartman foi (é) um corpo-com-órgãos, um corpo-com-pele, um corpo-com-aventalhotentote, um corpo-com (infinitas) pragas coloniais. Um corpo. Esta aberração Saartje Baartman, em estado de desmonte, foi colonizada, foi fetichizada. O fetichismo, segundo Stuart Hall (2016), envolve substituir por um objeto uma força poderosa e perigosa, porém proibida. Ele implica, portanto, a rejeição. O desejo ou fascínio é satisfeito, mas negado.

Hall vai dizer que no fetiche aquele que olha tem uma dupla-estratégia: ele representa e não-representa o objeto proibido; um voyeurismo não regulamentado, porém autorizado. (HALL, 2016:206) Sobre a Vênus Hotentote, o olhar foi deslocado da

\footnotetext{
${ }^{4}$ Maurice Leenhardt foi um pastor e etnólogo francês especializado no povo Kanak, da Nova Caledônia.
} 
genitália para as nádegas e isso autorizava ao observador a continuar olhando incansavelmente enquanto negava a natureza sexual do olhar. Os cientistas podiam observar Saartje Baartman nua, em público, classificar, dissecar cada detalhe de sua anatomia tendo um álibi absolutamente aceitável, até louvável: tudo era feito em nome da Ciência, do conhecimento objetivo, das provas etnológicas na busca da Verdade. Invisibilidade e superexposição, no que concerne às questões da ficção de raça, são sempre expressões do horror com nuances distintas.

Qual a razão da obsessão por Sarah senão fixá-la, e fixá-la dentro de um determinado sentido universal? Qual a razão da obsessão pela senhora Sarah senão repensá-la no questionamento sobre os limites desta representação? Sabe-se que é um corpo de mulher, e um corpo de mulher tornada negra, que é um corpo-hotentote, que é por isso um corpo-múltiplo, um corpo-língua, um corpo-mãos, corpo que vai inscrever/escrever as mulheres negras na geografia do mundo, e por decorrência, no que nós chamamos de nação, a partir de 1889. Nessa dinâmica passado-presente contínuo vamos incidir na reflexão de Frantz Fanon que se percebe desintegrado pelo olhar da pessoa branca; que o outro, através de olhares, gestos e atitudes, o fixou "como se fixa uma solução com um estabilizador" (FANON, 2008:103). O significado, no caso do negro, está dado a priori. A questão do negro é que:

[...] ele está preso na estrutura binária do estereótipo, dividida em dois extremos opostos, e é obrigado a ir e voltar entre um e outro infinitas vezes sendo representados como os dois ao mesmo tempo (HALL, 2016:200).

A produção do negro no espelho europeu envolve o que está subjacente, o que está pré-conceituado, determinado, em subtextos (e textos), que são fantasias projetadas da loucura. $\mathrm{O}$ espelho não diz respeito apenas a uma fantasia de Narciso, se relaciona com o pensar e orientar o mundo a partir de si e para si - uma forma de organizar utilitariamente a realidade à volta, a realidade dos outros em função da sua ou de seu grupo. Segundo Djamila Ribeiro, não é possível fazer um debate amplo sobre um projeto de sociedade sem encarar o modo como as identidades são forjadas dentro de uma lógica colonial. (RIBEIRO, 2017)

A raça é essa categoria fantasmagórica ficcional do horror, da loucura e do trauma, de onde é possível perguntar: o que é ser uma "negra, afro, simbólica, brasileira, diaspórica, subalterna, futurista, antropológica, tecnológica, contemporânea" Saartje Baartman? É ser também um número, uma fragmentação? É ser em partes? Pensemos 
que no Brasil 58,86\% das vítimas de violência doméstica são negras; 53,6\% das vítimas de mortalidade materna são negras; $65,9 \%$ das vítimas de violência obstétrica são negras; $68,8 \%$ das mulheres mortas por agressão são negras. Mulheres brancas ganham $70 \%$ do salário de um homem branco no exercício da mesma função. Mulheres negras ganham 40\% do salário de um homem branco no exercício da mesma função. 5 68\% das mulheres encarceradas são negras. (BORGES, 2018:91)

Segundo os dados apresentados na pesquisa "Avaliando a Efetividade da Lei Maria da Penha", produzido pelo Ipea (Instituto de Pesquisa Econômica Aplicada), em 2015, dentro dos aterradores números de feminicídio no Brasil, entre 2003 e 2013, houve uma alta do número de assassinatos de mulheres negras em $54 \%{ }^{6}$ No mesmo período o número de mulheres brancas caiu 9,8\%, conforme o Mapa da Violência de 2015. ${ }^{7}$ Há ainda os percentuais do desemprego; da população de rua; do manicômio... Há os números que dizem respeito à solidão da mulher negra; e outros ainda atrelados à violência psicológica. Todas viraram números, pedaços, estatísticas, fragmentações. São todos números. São todas número.

Se traçarmos um paralelo entre a forma como a medicina foi usada para ratificar o projeto de dominação europeu e o que apontam pesquisas recentes sobre a saúde da população negra vamos encontrar alguns fios soltos. Se, endossada pela legitimidade acadêmica e a pesquisa científica, a medicina "atestou" a inferioridade de determinados povos e serviu aos interesses coloniais, quando órgãos sérios de pesquisa divulgam dados aterradores sobre a saúde da população negra diante de uma população inerte, os tempos históricos parecem ser suplementares. Devemos nos perguntar porque intelectuais negros e ativistas da causa chamam a atenção para o fato de haver uma situação de genocídio da população negra e atrelam isso a práticas de instituições ligadas ao Poder Público. (BORGES, 2018) A Fundação Oswaldo Cruz divulgou uma pesquisa em 2015 que revelava que em uma busca por atendimento médico em maternidades públicas a peregrinação em busca de atendimento foi de $31,8 \%$ entre as negras e $18,5 \%$ entre mulheres brancas. A proporção de puérperas que não tiveram

\footnotetext{
${ }^{5}$ Os números são da Fiocruz, do Ministério da Saúde, do Ministério da Justiça, do 180 - Central de Apoio à Mulher, referentes ao ano de 2015. Conferir em: http://cultura.estadao.com.br/noticias/geral,pretasrecebem-menos-anestesia-imp-,703837; https://www.geledes.org.br/gravidas-pardas-e-negras-recebemmenos-anestesia-no-parto/ e https://www.geledes.org.br/brasileira-negra-ganha-menos-de-40-do-salariode-brasileiro-branco-diz-ipea/

${ }^{6}$ Conferir em http://repositorio.ipea.gov.br/bitstream/11058/3538/1/td 2048.pdf

${ }^{7}$ Conferir em http://www.mapadaviolencia.org.br/pdf2015/mapaViolencia2015.pdf
} 
acesso a esse procedimento foi maior entre as "pardas", 16,4\%, e entre as negras correspondeu a $21,8 \%{ }^{8}$ Ou seja: no momento do parto, mulheres negras foram mais penalizadas por não serem aceitas na primeira maternidade que procuraram e, também receberam menos anestesia. $\mathrm{O}$ atendimento seletivo é um dado, evidentemente, que sinaliza para a política de morte de que falávamos anteriormente. Além disso, o fato de mulheres negras não receberem anestesia na hora do parto nos faz lembrar da máxima do senso comum que diz que "o corpo negro suporta mais a dor". Não é esse o mito amplamente divulgado?

\section{Performatividade de si}

O ser negro é uma pilhagem que se move; uma desmontagem prisioneira de um corpo-mente; uma sensibilidade transiente, cunhada no trauma. Talvez por isso, como uma força insurgente encarnada, ele valore a performatividade como uma instância de luta aliada do ser negro no mundo. Tendo o corpo como patrimônio, e a marca/marcação da rejeição evidenciada na pele, este se torna um (o) campo potente do discurso de si. O corpo do negro está sempre em questão. Ele é, ao mesmo tempo, linguagem, patrimônio, memória, embate. A consciência do corpo, a tomada de consciência deste corpo negro, do corpo narrado, desloca uma gama de percepções e propõe outras tantas. Importa o como ele é narrado: a performance de si é neste sentido uma militância. Há na compreensão do discurso performativo da linguagem, e da linguagem de si, uma fratura histórica.

Quem legitima um determinado discurso? Quem produziu a Vênus Hotentote - a mulher-abjeto? E quem possibilita hoje o jogo de visibilidade e invisibilidade de tantas outras mulheres adversas que compõem o corpus social? É sempre a partir da exclusão, da opressão, da negação e da dor que as estratégias de poder se renovam e mantêm, se retroalimentam.

No decorrer dos processos históricos os negros sofreram infinitas formas de

\footnotetext{
8 As pesquisadoras Maria do Carmo Leal, Silvana Granado Nogueira da Gama e Cynthia Braga da Cunha, da Escola de Saúde Pública da Fundação Oswaldo Cruz, publicaram em 2015 um artigo na Revista de Saúde Pública da USP, que trazia os dados de uma pesquisa realizada em um universo de 9.633 puérperas (logo após o parto ou que deram à luz recentemente) entre 1999 e 2001. Destas, 5.002 eram brancas, 2.796 "pardas" e 1.835 negras. Os dados foram coletados a partir de prontuários médicos e em entrevistas com as mães no pós-parto. Conferir em https://www.geledes.org.br/gravidas-pardas-enegras-recebem-menos-anestesia-no-parto/
} 
violência física, moral, ética, psicológica, emocional (bem como material, imaterial e de pilhagem histórica), que dizem respeito à alocação do indivíduo nesse tecido social, a manutenção de um status quo específico, mas também a formação do sujeito e de sua subjetividade formada a partir da opressão - e estas duas constatações, dimensões de um desmonte ontológico, estão imbricadas uma na outra. Foi-lhe negado o direito à subjetividade, ao espírito, ao afeto, à fragilidade. Isso é parte da experiência do ser negro, da sua memória esburacada, é aquilo que a faz vibrar, estremecer, encrespar. No que concerne aos padrões de representação, ela está constantemente atrelada a violência que tem moldado o imaginário, em enunciados e incitações de interpretação, a olhos vistos ou nos porões impenetráveis de nossa mente negreira - com violência, explícita ou implícita. É esta linguagem que penetra os corpos que foi moldada nos padrões coloniais.

Uma política de representação é uma prática de produção de significados, sendo a significação portadora de uma determinada mensagem, que diz respeito a alteridade, esta que numa lógica polarizada de interpretação, constantemente atrela a raça à diferença, exclusivamente. No regime de representação vigente há violência simbólica, há opressão simbólica, na medida em que engessa pressupostos ideológicos como processos naturais de interação social. Por isso, a forma como uma mensagem é interpretada está em constante vigilância por grupos que se preocupam com a questão racial, no Brasil e no mundo. A alteridade é formulada a partir de práticas representacionais que através da estereotipagem fixaram um determinado repertório no âmago de nossa cultura. O repertório está relacionado com o lugar social que um indivíduo ocupa, seu pertencimento - a que ele "serve". O racismo, como tecnologia de poder, acompanha o desenvolvimento histórico, atravessa as transformações da sociedade e a baliza, estruturando o seu DNA. Ele coloca em movimento o corpo social, onde a engrenagem sistêmica, o músculo nefrálgico da nação, se sustenta através de desigualdades baseadas em hierarquias raciais - sempre com violência: seja ela violência física ou pela linguagem.

No sentido de Homi Bhabha (1997), a nação é uma narração, onde o valor pedagógico conferido aos objetos nacionais (tradição, povo, razão do Estado, alta cultura) vai fornecer um (certo) campo de significações associados à vida nacional. Se olharmos o fluxo dos tempos como quem olha por aquele retrovisor do carro, nosso olhar será capturado pelo quintal de uma casa grande, que está lá, feia, porém 
alicerçada. Nesta casa, duas pinturas: uma Vênus ocupa o centro da parede do salão principal, a outra figura atrás da porta dos fundos. Se uma terceira eleva as mãos pretas sob um céu colonizado, a outra nutre um meio sorriso incógnito ladeada por uma alegria plácida, alva e febril. ${ }^{9}$ Gerações posteriores ao sistema escravagista são moldadas num mesmo imaginário comum. O racismo está no centro da dinâmica de poder como estratégia de controle, de forma totalmente naturalizada. No Brasil, quem nunca ouviu dizer que "é preciso clarear a raça"? Quem nunca tomou ciência de uma cultura fixada como menor, até marginalizada? Quem não passou parte da vida em contato com uma literatura que ou invisibilizava os indivíduos negros ou os estereotipava? Quem nunca atrelou a participação de negros no contexto social exclusivamente às esferas da cultura (nas manifestações populares) e do esporte? É possível pensar estes campos como lugares que inserem no imaginário, de forma temporal, pontual e segmentada, uma antiga ideia construída por interesses classistas que dão margem para pensar uma inclusão abstrata? Quem não pensou uma mulher negra nos termos do estereótipo? Quem nunca teve uma atitude racista?

A exclusão e a subalternidade, o apagamento e o silenciamento se configuram como os novos manejos da negação, onde o domínio sobre os corpos ainda é poder. Quando o pós-moderno global passa da hostilidade e negação à um "gosto" pela "diferença", pelo "exótico", isto se dá como resultado das políticas culturais da diferença. Hall (2003), entretanto, em seu ensaio "Que negro é esse na cultura negra (HALL,2003:337), indo na contramão de um otimismo ou de um pessimismo polarizados, faz referência a um ensaio de Michele Wallace, e pontua que ela acertou ao indagar se a proliferação da diferença, essa ascensão do pós-moderno global, não seria uma repetição de um jogo de esconde-esconde, que o modernismo jogou com o primitivismo no passado. O jogo não estaria sendo novamente realizado "à custa do vasto silenciamento acerca da fascinação ocidental pelos corpos de homens e mulheres negros e de outras etnias" (WALLACE apud HALL, 2003:337)? Essa autorização do olhar a que a proliferação da diferença convida ao mesmo tempo em que rejeita, não seria um tipo de diferença que não faz diferença alguma? Nas palavras de Néstor García Canclini (2003), um tipo de inclusão abstrata e exclusão concreta?

Sobre o negro existem momentos distintos da negação de sua pertença mútua no mundo. Contudo, para Achille Mbembe (2014), o que vivemos hoje caracteriza-se como

\footnotetext{
${ }^{9}$ Ver a pintura a óleo “A Redenção de Cam”, de Modesto Brocos, de 1895.
} 
um ambiente em que a experiência da exclusão não se restringe apenas e unicamente à condição negra; desloca-se, enquanto ideia de negação, para outros corpos subalternos. A experiência fundamental de nossa época é então esta, a da subalternidade; são as experiências dos outros do mundo. Nesse "devir negro"10, qual o papel do negro e da raça (essa entidade do assombramento), sendo essas instituições centrais que sustentam o discurso euro-americano? Como pensar o mundo onde todos (inclusive a Europa) se encontram em crise e na expectativa do novo? Como ler este mundo onde o medo une "diferentes", onde o terror não é apenas circunstancial às categorias atreladas a racialidade (ainda que para negros ele se apresente com nuances distintas)? Como pensar, por exemplo, uma Europa deslocada de sua centralidade classificatória, discursiva, histórico-centralizada? Essa nova condição determinará a extinção do racismo ou ele vai se reelaborar, reconfigurar e encontrar sua nova face do espanto?

A opressão encontra as formas de mascarar o óbvio, dispõe as peças do jogo como forma de organização social. Da mesma maneira o racismo encontrou diversas vezes seus mecanismos de reinvenção, como manejo político para fins de manutenção do poder e circulação do capital. Novas formas de imposição para aplicação do mesmo. Seja através de uma etnicidade ficcional, seja através da necropolítica (MBEMBE, 2016), ou do regime de representação em suas investidas de inclusão/exclusão, haverá disputa através da linguagem. A existência dentro da circunscrição negra confere ao sujeito uma carga experiencial além de uma carga simbólica, e ambas continuam atreladas. Dentro de sua experiência paradoxal, de sua existência história, de sua configuração transmutacional, o negro é, portanto, a priori e devir. Ambivalência e paroxismo. O ser negro é esta pilhagem nômade, ação e reação, desmontagem, transmutação. Na potência das fantasias que existem coletivamente há processos de luta, operação simbólica, fabulação, recuperação, deslocamento de subjetividades subalternizadas. O imaginário é um campo potente do discurso. É nele primeiramente que as lutas identitárias têm ganhado força. É na encruzilhada de caminhos que a estereotipagem, o regime de representação e a definição de raça continuam a se debater na histeria de engessar o sujeito nas fronteiras de um código, de uma demarcação social.

\section{Esteriotipização do corpo feminino negro}

\footnotetext{
${ }^{10}$ (MBEMBE, 2014:18) “[...] a este novo caráter descartável e solúvel, à sua institucionalização enquanto padrão de vida e à sua generalização no mundo inteiro, chamamos o devir-negro do mundo".
} 
Vamos avançar aqui para a questão basilar dos estereótipos raciais fabricados em tempos coloniais e que contaminam as relações sociais contemporâneas. São ideias como a do negro altamente sexuado/selvagem; da fêmea objeto de uso (que servia aos extintos e desejos dos senhores brancos - que tanto eram estupradas pelos brancos, como tinham de "emprenhar" de escravos reprodutores); da ama de leite/"mãe preta"; de seres dotados de força física própria ao trabalho braçal, entretanto sem habilidades intelectuais; ligados à natureza; preguiçosos, apesar de destinados à servidão. A natureza era o destino; como em Sarah, lembremos: a Europa estava para a Ciência assim como a África estava para a natureza; a Europa estava para a razão, assim como a África estava para a emoção; a Europa representava a cultura enquanto a África era o primitivo. As representações que nos inventaram como novo mundo, e que mais tarde nos moldaram enquanto nação, são as mesmas que reconhecemos nas relações sociais que vigoram hoje. Elas implicam todas as esferas da vida, pública e privada. O imaginário como espaço político se tornou crucial para toda a questão que envolve a etnicidade, e a etnicidade fictícia, no sentido de que fala Etienne Balibar (2007), como uma fabricação. A imagem se coloca como lugar de falas plurais, como plataforma de enfrentamento de um projeto de sociedade ainda ancorado em processos discriminatórios em suas formas de supressão e reificação de determinados arquétipos identitários.

Nos tipos em que o negro está inserido no regime de representação e visibilidade, do teatro ao cinema, passando pelas novelas e pela publicidade, sem esquecer-se da literatura, a distinção está delimitada e fechada nos termos do estereótipo. As políticas racializadas da representação naturalizam e encerram estes sujeitos dentro de um quadro de estabilidade. Quando as supostas diferenças entre indivíduos brancos e negros são culturais, podem ser alteradas; porém, se são consideradas "naturais", estão fixas no tempo. Há fechamento discursivo e ideológico.

Joel Zito Araújo (2000), em seu importante livro “A Negação do Brasil”, sobre a presença de negros na telenovela brasileira, aborda uma pesquisa de Donald Bogle (1973), através da qual também é possível identificar a presença dos mesmos tipos em distintos seguimentos da comunicação e da cultura. O livro "Toms, Coons, Mulattoes, Mammies and Bucks: an interpretative History of Blacks in American Films" (1994) aponta cinco estereótipos principais presentes nos filmes norte-americanos que Zito 
reconhece também na cultura brasileira:

1. Pai Tomás - os bons negros; mesmo que perseguidos e desgraçados, "mantêm a fé, jamais se voltam contra os brancos e mantêm-se saudáveis, submissos, estoicos, generosos, altruístas e oh!, tão gentis";

2. Os malandros (coons) - os "pequeninos", de olhos arregalados, os animadores de pastelão, criadores de histórias mirabolantes, inúteis que não servem para nada a não ser "massacrar a língua inglesa".

3. A mulata trágica - a mulher aprisionada em sua herança racial dividida, desejável, porém condenada a final trágico por conta de seu "sangue negro".

4. As mães pretas - com sua absoluta devoção à casa dos brancos e subserviência inquestionável, protótipos da servente doméstica, geralmente gorda, mandona, intratável com o marido (que, aliás, não serve para nada);

5. Os mal-encarados (bad ducks) - grandes, fortes, violentos, renegados, imprestáveis, selvagens, extremamente sexuados, "agressivos e cheios de fúria negra", "frenéticos, pois desejam a carne branca" (ARAÚJO, 2000:47).

A subalternidade é constantemente representada pelo negro. Para além da questão social/classe (mas não excluindo a importância dela para a temática identitária) a complexidade do humano e das relações humanas é o que raramente está presente nas representações da raça na cultura popular. Nos tipos citados, não há humano, há caricatura. Há, como no caso disparador desta reflexão, Sarah, um exemplo de fechamento. A experiência da subalternidade tem sido a potência de nossa época, mas também o seu quinhão. Lidar com o "já dado" é deslocar o sentido, mas também observar o fato de que é, muitas vezes, estar fadado a uma nova armadilha da diferença, de aprisionamento. É possível transmutar Saartje Baartman? Como é possível incinerar esse tropo?

Refletir sobre estas questões é perlaborar dentro de um trauma coletivo, que ganha força na reflexão sobre a existência da Vênus Hotentote, mas também tenciona a possibilidade de continuidade da força motriz de sua existência enquanto personagem, através de uma "categoria", de uma tipificação como a da "mulata trágica", apontada por Donald Bogle. Trazendo para a ceara de Joel Zito Araújo reconhecemos as "mulatas" e as "mães pretas" em nossas narrativas: aplaudimos as mulatas "da cor do 
pecado"; uma geração chorou com "A cabana do Pai Tomás"11 a moda brasileira; rimos com tantas vizinhas negras desocupadas, atrevidas e fofoqueiras; odiamos as empregadas salientes que seduziam seus patrões, homens de bem. A fixação na sexualidade perpassa as mudanças históricas e atrela novamente o corpo negro aquilo que é promiscuo, condenável, ao prazer e ao erro. A obsessão em relação ao corpo da mulher brasileira, marcado pela experiência negra, ficcionalizada na figura da mulata, a exclusão desta mesma mulher nos processos de clivagem social, seu potencial de uso, comungam com passados primitivos.

A mulata $^{12}$ é uma representação simbólica, ela mora na zona fronteiriça de um domínio excludente. É um híbrido, portanto. Ela é e não é; como signo é uma invenção, uma composição e ao mesmo tempo uma desmontagem. Basicamente a literatura se refere à mulata fazendo associações com gostos e cheiros. Com sabores. Com coisas de comer. Seu estatuto simbólico diz a respeito dela e a inscreve no mundo. A mulata sequer é identidade, ela é uma espécie de categorização existencial. Por ter sua natureza amenizada pela presença dos genes brancos, ela é aprazível. O fetiche e a rejeição caminham novamente juntos aqui. O signo aprisiona e encerra uma gama de possibilidades, nele não há movimento. Nisso também a mulata é trágica. É marginal. Ela não pertence, não serve. A mulata serve para. A mulata não possui. A mulata é em partes. A mulata é negra. (PACHECO, 2008)

No Brasil, a mulata está encerrada num tropo, nas amarras do estereótipo e do fetiche. Nas formas de representação ela está associada a uma mercadoria, ao uso de seu corpo não importa os fins. Se pensarmos nos objetos artísticos como inseridos em processos pedagógicos para nos construir como nação, teremos exemplos distintos, em décadas díspares. Arthur Azevedo, abolicionista, não escapou de nos apresentar a personagem Benvinda, da peça A Capital Federal (1897), uma "mulata" jeitosa e dengosa, cria da casa, inculta e caipira, encantada pelos fascínios da cidade grande, mas que ao final do enredo se encontra gratíssima por voltar ao seio da casa onde se criou.

\footnotetext{
${ }^{11}$ Novela exibida na TV Globo entre 1969 e 1970, baseada no romance "Uncle Tom's Cabin", em que Sérgio Cardoso "pintado" de preto (black face) encarnava o protagonista e Ruth de Souza vivenciava a primeira protagonista negra da história da televisão brasileira, sofrendo ataques de parte do elenco: algumas atrizes brancas não queriam que o nome delas viesse depois do nome de Ruth, mesmo ela vivendo a protagonista.

${ }^{12}$ A etimologia da palavra se refere ao cruzamento de animais. A palavra mulata é de origem espanhola, feminino de "mulo", um animal híbrido, resultado do cruzamento de cavalo com jumenta, ou jumento com égua. Os termos mulato e mulata foram usadas de forma pejorativa para denominar os filhos de pessoas negras com brancas (mestiços).
} 
Outro personagem do texto é Figueiredo, cuja atividade é "lançar mulatas" no demimonde carioca.

Aluísio Azevedo, em 1890, criou Rita Baiana, personagem do livro "O Cortiço" (2005). Rita é a projeção do estereótipo de mulher mulata brasileira: ela é bonita, sedutora, maliciosa, fogosa, mas ao mesmo tempo moldada pela sociedade, por quem Jerônimo, um homem honesto, é até capaz de matar. E esses exemplos inundam o nosso imaginário, foram conservados, em outra dimensão, pela cultura nacional. Os exemplos dizem respeito a corpos "iguais", porém muito distintos: são corpos iguais na forma, mas não no modo como significam. A linguagem penetra os corpos. Se ao início sustentamos a ideia do cotidiano como político, agora tateamos a reflexão da estética como política.

$\mathrm{Na}$ área da música podemos, entre outros exemplos, verificar a canção de Alberto de Castro Simões da Silva (Bororó), que, ao final da década de 30, cantava uma música que fazia menção aos "beijos molhados e escandalizados" de uma morena "da cor do pecado":

\begin{abstract}
Esse corpo moreno cheiroso e gostoso que você tem/ É um corpo delgado da cor do pecado/ Que faz tão bem/ Esse beijo molhado, escandalizado que você me deu/ Tem sabor diferente que a boca da gente/ Jamais esqueceu/ E quando você me responde umas coisas com graça/ A vergonha se esconde/ Porque se revela a maldade da raça/ Esse cheiro de mato tem cheiro de fato/ Saudade, tristeza, essa simples beleza/ Esse corpo moreno, morena enlouquece/ Eu não sei bem por que/ Só sinto na vida o que vem de você/ Ai....Ai...
\end{abstract}

Novamente Sarah não está distante de nós. Semelhante a Fanon aqui há o olhar do outro que constrói e fragmenta, que aponta a alguém quem ele é. As partes do seu corpo foram expostas nuas e em praça pública, diante de olhares devidamente autorizados. Um corpo de mulata ao entrar em um ambiente carrega uma narrativa que o superexpõe. E quando foi que a mulata começou a aprender a ser Vênus? Ou ela não aprendeu? Ou ela não é? Altas doses de apelo erótico, a exposição corporal e a fetichização do corpo (e das imagens atreladas a ele) não têm com extrema frequência dado o tom do trabalho musical que vão apresentar tantas artistas contemporâneas; elas, apoiadas no mesmo tropo sobre o qual refletimos, não estão endossadas por um público que lhes intitula como sucesso? Também neste caso o olhar sexual está autorizado, mas agora em nome da arte? Este "corpo aos pedaços", capturado em planos detalhes (no showbiss ou nas festas populares) é um pouco Sarah- Baartman? E quanto a quem 
endossa e justifica o show, esse olhar, o que é?

Nossa cultura propõe uma inversão para o termo mulato, em oposição ao discurso oriundo das teorias eugenistas do século XIX, segundo as quais a miscigenação deveria ser combatida, como principal responsável pela possível degeneração e consequente extermínio da raça humana. Para usar o termo de Roberto DaMatta (1984), tratava-se de uma "cristalização perfeita". A mulata é uma anomalia para eugenistas, uma derivação para "nacionalistas" e não é coisa alguma, por ser apenas uma fantasia/fantasmagoria. Uma "entidade" fictícia que existe fora do indivíduo e se sobrepõe a ele. Nela a exaustão dos tempos está toda concretizada. Quantas são as implicações da estereotipagem? O que as práticas discursivas dizem sobre a identidade de mulheres racializadas, para quem os duplos são triplas inscrições de subalternidade codificada? É comum, e também, neste sentido, problemático, que o indivíduo e o grupo representem com frequência a mesma coisa.

No sentido histórico, a obrigação ao esquecimento/apagamento se iguala a construção de discurso sobre uma sociedade que desempenha a "totalização" como forma de um desejo de nacionalidade. Se é a partir das tradições do pensamento político e da linguagem literária que a nação vai surgir no Ocidente, como uma poderosa ideia histórica, nas novas falas, nos modos de dizer, nos deslocamentos de lugares, na apropriação do próprio corpo e da imagem de si, não há sentimento comum, não há unidade. Há um processo em curso de tornar-se livre, onde agentes históricos mobilizam um processo contínuo de abolição. Mesmo com estas investidas tendo se iniciado nos processos de luta dos povos escravizados, em seus processos de revoltas e resistências, elas não atingiram a sua completude. Posto que os movimentos contrários estão também em curso. Há nesta percepção uma dinâmica de passado-presente que está em jogo, no aqui, sempre agora. Ainda é preciso descolonizar o discurso; estriar o corpo; repensar as bases epistêmicas do saber. O gesto de (re)educar o olhar requer fraturar o discurso e operá-lo.

\section{Observando o novo pelas fissuras}

A questão contemporânea passa pela diversidade, pela junção daquilo que é universal com a diferença. No sentido de Kwame Appiah (1985), a diferença é complementar. No cerne de uma reflexão ética o lugar de complemento se dá no 
“entre”, não mais na configuração do contexto de Sarah, mas sim em um novo lugar de escuta e de fala, um diálogo que se estabelece através das diferenças. A "conversação cosmopolita" (APPIAH, 1998), segundo o autor ganense, passa por barreiras políticas, sociais, econômicas e culturais. Mas ainda é através das ciências humanas e dos meios de comunicação que poderemos conversar com "outros" do mundo. Assim, na perspectiva da pluralidade e da falibilidade, ele vai esclarecer que não aprendeu a ser cosmopolita na Inglaterra ou nos Estados Unidos, mas em Gana, seu país natal, numa lógica de mundo compartilhado. Nesta mesma linha de reflexão, Achille Mbembe vai dizer que só há mundo se todos possuem direito a ele. No sentido de uma comunidade universal, a restituição e a reparação são centrais para a possibilidade de construção de uma consciência comum de mundo, isso porque:

O negro é, na ordem da modernidade, o único de todos os seres humanos cuja carne foi transformada em coisa, e o espírito, em mercadoria - a cripta viva do capital. Mas - e esta é a sua manifesta dualidade -, numa reviravolta espectacular, tornou-se o símbolo de um desejo consciente de vida, força pujante, flutuante e plástica, plenamente engajada no acto de criação e até de viver em vários tempos e várias histórias ao mesmo tempo. A sua capacidade de enfeitiçar e, até, de alucinar multiplicou-se. Algumas pessoas não hesitariam em reconhecer no negro o lodo da terra, o nervo da vida através do qual o sonho de uma humanidade reconciliada com a natureza, ou mesmo com a totalidade do existente, encontraria novo rosto, voz e movimento (MBEMBE, 2014:19-20).

Como é ser Saartje Baartman em construção ontológica? Ser/estar na fissura do semelhante e do dissemelhante, do que é diferente e do que é "em comum", do ser e não ser? Lembremos de "Dona" Saartje: a mulher-macaco; a mulher-orangotango; a mulhernádegas; a mulher-coisa; a mulher-objeto; a objeto-coisa; a macaco-nádegas; a coisamulher; a orangotango-coisa. Para nós, que falamos e pensamos na língua (e nos signos) do colonizador, o que é? No cerne da inquietação, essa involução criativa: "a natureza", que age contra ela mesma, em instabilidade perpétua, classifica apenas que a diferença é (e não é) a própria vida. De certa forma, ela desqualifica, desclassifica e habilita. Para alguns grupos viver é por si só um ato de rebeldia.

\section{Referências}

ADICHE, Chimamanda Ngozi. Sejamos todos feministas. São Paulo: Companhia das Letras, 2015.

ALIGHIERI, Dante. A Divina Comédia. Fonte Digital. São Paulo: Atena Editora, 2003. Disponível em: http://www.dominiopublico.gov.br/download/texto/eb00002a.pdf 
ANDERSON, Benedict. Comunidades Imaginadas. Reflexões sobre a origem e a difusão do nacionalismo. Tradução Denise Bottman. São Paulo, Companhia das Letras, 2008.

ANGELA, Davis. Mulheres, raça e classe. São Paulo: Boitempo, 2016.

APPIAH, Kwame Anthony. "Patriotas cosmopolitas". Revista Brasileira de Ciências Sociais, $\mathrm{n}^{\circ} .13$, vol. 36 , fev. 1998.

ARAÚJO, Joel Zito. A negação do Brasil. O negro na telenovela brasileira. São Paulo, Editora Senac. 2000, $1^{\mathrm{a}}$ edição.

AZEVEDO, Aluísio. O cortiço. São Paulo: Companhia das Letras, 2005.

AZEVEDO, Arthur. A Capital Federal. Rio de Janeiro: Ediouro. (Prestígio), 1897. Disponível

em http://objdigital.bn.br/Acervo_Digital/Livros_eletronicos/A\%20Capital\%20Federal.pdf

BALIBAR, Etienne. "La forme nation: histoire et idéologie". In: BALIBAR, Etienne; WALLERSTEIN, Imanuel. Race, Nation, Classe. Les identités ambiguës. Paris: Lá Decouverte, 2007.

BHABHA, Homi K. "Nation and Narration". In: Nacionalidade em questão. Org. Maria Helena Rouanet. Cadernos da Pós/Letras - I.L. 1997

O local da cultura. Belo Horizonte: Editora UFMG, 1998.

BENJAMIN, Walter. Rastro, aura e história. Belo Horizonte: Editora UFMG, 2012.

BOGLE, Donald. Toms, Coons, Mulattoes, Mammies and Bucks: An interpretative History of Blacks in American Films. Nova York: Continuum Publishing, 1994.

CANCLINI, Néstor García. Culturas Híbridas. Estratégias para entrar e sair da modernidade. Tradução brasileira: São Paulo: Editora Universidade de São Paulo, 2003. 4a Edição.

DAMATTA, Roberto. O que faz do Brasil, Brasil?. Rio de Janeiro: Editora Rocco, 1984.

DELEUZE, Gilles; GUATARI, Felix. Devir-intenso, devir-animal, devirimperceptível. Tradução brasileira: Suely Rolnik. Mil platôs - capitalismo e esquizofrenia. Rio de janeiro: ed. 34, 1995.

EVARISTO, Conceição. Olhos D’Água. Rio de Janeiro: Pallas: Fundação Biblioteca Nacional, 2016.

FANON, Frantz. Pele Negra, máscaras brancas. Tradução Renato da Silveira. Salvador: EDUFBA, 2008.

FOUCAULT, Michel. Em defesa da sociedade. Tradução brasileira: São Paulo: Martins Fontes, 1999.

Graal, 2003.

"Verdade e poder". In: Microfísica do Poder. Rio de Janeiro: Edições

GIL, José. "O Corpo Paradoxal". In: LINS, Daniel; GADELHA, Sylvio (Orgs.).

Nietzsche e Deleuze: Que pode o corpo. Rio de Janeiro: Relume Dumará, 2002.

Disponível em https://territoriosdefilosofia.wordpress.com/2015/04/22/o-corpoparadoxal-jose-gil/.

HALL, Stuart. Cultura e representação. Tradução brasileira: Rio de Janeiro: Editora PUC-Rio, 2016.

Da Diáspora. Identidades e Mediações Culturais. Tradução brasileira: Belo Horizonte: Editora UFMG, 2003. $1^{\text {a }}$ edição.

HUBERMAN, Didi. O que vemos, o que nos olha. Tradução Paulo Neves. Coleção 
Trans, Editora 34.

MBEMBE, Achille. Crítica da razão negra. Tradução portuguesa: Marta Lança. Lisboa: Editora Antígona, 2014.

. "Necropolítica". Revista Arte \& Ensaios, n". 32, 2016.

PACHECO, Ana Cláudia Lemos. "Branca para casar, mulata para f... e negra para trabalhar"; escolhas afetivas e significados de solidão entre mulheres negras em Salvador, Bahia. Ana Cláudia Lemos Pacheco. - Campinas, SP:, 2008.

RIBEIRO, Djamila. O que é lugar de fala?. Belo Horizonte: Letramento: Justificando, 2017.

SANTIAGO, Silviano. Uma literatura nos trópicos. Rio de Janeiro: Rocco, 2000.

Vênus Negra. Dir. Abdellatif Kechiche. Rot. Abdellatif Kechiche e Ghalia Lacroix. Perf. Yahima Torres, Olivier Gourmet, André Jacobs, 2010.

\title{
OTHER STORIES
}

\section{THE VENUS, THE EYE AND THE MULATA IN ONTOLOGICAL DISMOUNT}

\begin{abstract}
This essay seeks to reflect on the construction of a stereotyping of the black female body from, principally, the character Saartje Baartman, the Venus Hottentot. The contemporary issue involves diversity, through the union of what is universal with difference. The difference is complementary. At the core of an ethical reflection, the place of complement takes place between, not in the configuration of the context of Saartje, but in a new place of listening and speaking, a dialogue that establishes itself through differences.
\end{abstract}

\section{Keywords}

Saartje Baartman. Difference. Necropolítica. Stereotyping. Diaspora. 